Матеріали Всеукраїнської науково-практичної конференції «Актуальні питання діагностики, лікування, раціональної фармакотерапії, диспансеризації та реабілітації в практичі сімейного лікаря"

УДК 616.24-002.5:612.233/25:577.3

DOI

\title{
БІОФІЗИЧНА ХАРАКТЕРИСТИКА ВОЛОГИ ПОВІТРЯ, ЩО ВИДИХАЄТЬСЯ, У ХВОРИХ НА ТУБЕРКУЛЬОЗ ЛЕГЕНЬ У ДИНАМІЦІ ЛІКУВАННЯ
}

○Ю. І. Бажора, П. П. Єрмуракі, М. М. Чеснокова,

О. О. Сметюк, Алі Слеман Саєб Абдулрахман

Одеський національний медичний університет

Волога повітря, що видихається, привертає увагу як матеріал для вивчення біологічних компонентів. Пов'язано це з тим, що конденсат вологи повітря, що видихається (КВВП), формується в альвеолах легеневої тканини і його складові відображають стан місцевого гомеостазу системи дихання. Крім того, метод отримання КВВП належить до неінвазивних, що також привертає увагу дослідників.

У попередніх дослідженнях нами була показана діагностична цінність методу лазерної кореляційної спектроскопії (ЛКС) у дослідженнях біофізичних властивостей КВВП при захворюваннях органів дихання [1].

Метою даної роботи є оцінка стану місцевого гомеостазу при проведенні специфічної хіміотерапії у хворих на вперше діагностований туберкульоз легень за даними ЛКС-метрії КВВП.

Дослідження були проведені у 143 хворих на туберкульоз легень на початку і після завершення стандартизованого двомісячного курсу інтенсивної терапії. Контролем служила група з 80 здорових осіб. КВВП отримували за описаним нами раніше методом. Зразки досліджували на ЛК-спектрометрі «ЛКС-03». Аналізу підлягали усереднені ЛК-спектри КВВП певних груп з використанням семіотичного класифікатора.

Отримані результати свідчать про існування порушень місцевого гомеостазу у хворих на туберкульоз. Особливості метаболічних зрушень в ЛК-спектрах залежать від характеру перебігу туберкульозного процесу. Так, при більш обтяжених формах (дисемінованому туберкульозі, наявності деструкції, бактеріовиділенні і резистентності до протитуберкульозних препаратів) катаболічна спрямованість метаболічних зрушень з помірним і вираженим ступенями проявів (50,35 \%) превалює над анаболічною (26,58 \%) та змішаною (23,07 \%).

Після проведеної двомісячної фази інтенсивного лікування в характері ЛК-спектрів спостерігали істотні зміни в позитивну сторону. У всіх групах хворих (інфільтративна і дисемінована форма туберкульозу, процес без деструкції і з деструкцією легеневої тканини, МБТ+ і МБТ-, чутливість і резистентність до хіміотерапії) спостерігали істотне зниження ступеня зрушень в ЛК-спектрах і перерозподіл співвідношення їх характеру за рахунок зниження числа катаболічно спрямованих зрушень у більшості із зазначених груп (37,76 \%). У певної кількості хворих з анаболічним і змішаним типами ЛК-спектрів КВВП $(18,18$ \%) ступінь метаболічних порушень змінився до початкового, що може свідчити про зниження ступеня вираженості патологічного процесу.

Висновок. Дослідження КВВП методом ЛКС дозволяє визначити характер і ступінь вираженості метаболічних зрушень у дихальній системі хворих на туберкульоз. 3 урахуванням неінвазивності методу отримання досліджуваних зразків та виявлення порушень переважно місцевого гомеостазу, дослідження КВВП методом ЛКС може бути одним з методів моніторингу ефективності лікування хворих на туберкульоз. 